\title{
Obama taps new allies and tackles age-old divisions in nudging health care reform
}

Published at www.cmaj.ca on Dec. 10, 2009

Y ou could say United States President Barack Obama is living up to the title of his book as his fight to reshape US health care enters its most crucial days. Talk about The Audacity of Hope.

He's taken on this colossus in the midst of economic calamity, two wars, a heaving national debt, tepid popularity and partisan sniping that makes even incremental change a tough sell in Washington. He's done so despite a leadership style more deliberative than daring, and with keen knowledge of the perilous history of diving into health care politics.

Congress is engaged in intensifying debate, pushed by Democratic leaders who are racing to get legislation through the Senate by Christmas after having prevailed in the House of Representatives in the fall.

If it goes well, Obama could have a transcendent domestic achievement to trumpet in his next State of the Union speech, one that eluded towering figures of the past.

At the moment, though, that union is in a state of bewilderment about the whole messy thing.

"There's been a slow, gathering consensus since the collapse of 'Clinton care' (15 years ago) that this is a problem whose solution is overdue," says Will Marshall, founder and president of the Progressive Policy Institute, an influential centrist Democratic think-tank. "What's really driving that is out-of-control costs. What's been fascinating is to watch public doubts rise. What was overwhelming public support for action has now become a much more ambivalent picture."

Republicans have spared no effort to give people the willies about what the president wants to do, even raising the ghoulish specter of federal "death panels" arising from "Obamacare." Democrats are seeing internal fractures and

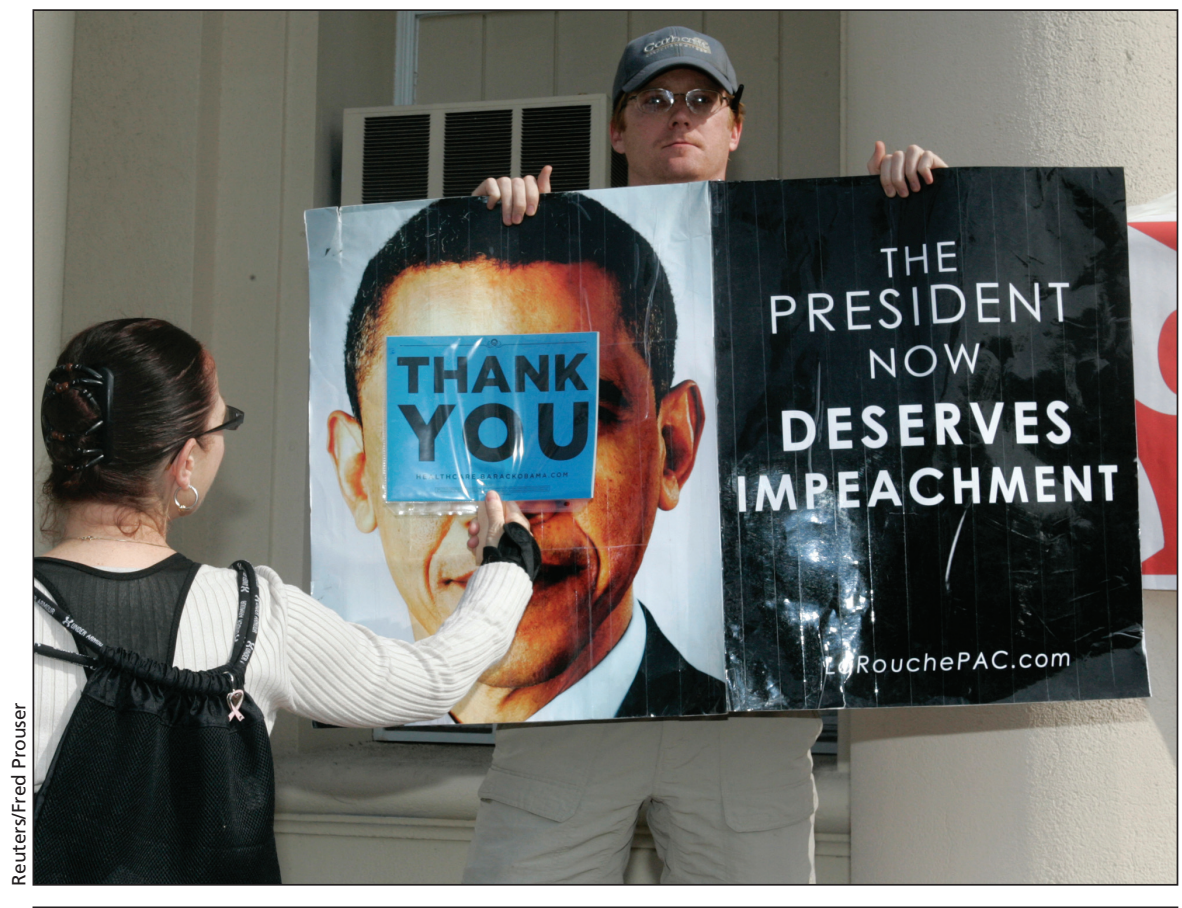

United States President Barack Obama's proposed health care reforms prompted impassioned debate. Here, a health care reform supporter blocks a sign held by a Lyndon LaRouche supporter during a health care prayer rally last summer in Hollywood, California.

putting their congressional majority on the line in 2010 elections. Special interests are in roiling motion.

Although Obama's legacy will be largely set by the outcome of this struggle, he seems to be the only calm figure around. He's practically Zenlike that way.

"We're closer to that significant reform than at any time in recent history," he has repeatedly said. "That doesn't make it easy. It's hard."

Americans tend to badmouth their health insurance system until someone tries to change it. Then they fear legislators will throw out the good with the bad, saddling taxpayers with expensive new entitlements and overbearing government. The lobbyists weigh in, conservative activism is ignited and a status quo that leaves some 40 million without health insurance lives on.
This time, it just might be different.

By any measure, the US is closer to a reinvention of health insurance than it's been for generations. Not since Lyndon Johnson won Medicare and Medicaid health coverage for the elderly and poor in 1965 has the country proposed such sweeping health change.

The House and Senate bills, differing in their reach, share bottom-line principles in seeking to bring millions more into the system and prohibiting insurers from denying people coverage.

They would require nearly all Americans to carry health insurance, with subsidies to make plans affordable to more people and businesses. New markets would help workers in small companies and the self-employed obtain coverage now beyond their means. Billions in new fees (such as various new levies on 
drug makers, health insurers, medical device manufacturers and clinical laboratories), higher taxes on the rich and Medicare cuts would help pay the cost, roughly US\$1 trillion over 10 years.

None of this is Canadian-style health care - not even close.

Advocates of a single-payer system like Canada's were brushed aside in a wave of polemic (CMAJ 2009; DOI: 10.1503/cmaj.109-3027). For that matter, so were critics who warned that ailments of the Canadian system would infect the US if Washington went down the road of more federal intervention.

"I don't find Canadians particularly scary," Obama cracked at one point, "but I guess some of the opponents of reform think that they make a good boogeyman."

Still, he said of the two countries, "We've evolved differently." The US must "develop a uniquely American approach to this problem."

The legislative horse-trading is fierce. Ten days into the Senate debate, Democrats agreed to jettison their proposal for a government insurance plan to compete with private insurers, settling instead for limited nonprofit plans that would be overseen by Washington. This major concession to conservatives brightened chances the Senate bill will pass but opened conflicts with the House legislation, which has a government plan firmly embedded.

Then a different point of division arose as a few senators pushed to amend their bill to ease imports of cheaper drugs, mainly from Canada. The Obama administration pushed back, clearly reluctant to alienate US drug makers who have become key allies in the broader reforms.

Uninsured Americans have always lacked the political clout to achieve the reforms necessary to bring them into the system. Now, every Democratic plea to cast a safety net to the uninsured is paired with an appeal to middle-class self-interest.

It's not just about getting sick without coverage, says Senator Harry Reid of Nevada, the Senate Democratic leader, but about rising bankruptcies, lost jobs and squeezed budgets afflicting those who pay staggering insurance costs.

Premiums for plans provided in the workplace - the way most Americans get coverage - have doubled since 2000. The government estimates it will cost employers and workers an average US\$19 000 a year by 2016 for a plan for a family of four.

That drag on the economy has helped bring some powerful lobbies onboard, in part to ensure the outcome doesn't stomp on their interests.

In a striking turnaround, the American Medical Association (AMA) is supporting the initiative. One of US history's leading voices against "socialized medicine," the AMA battled Medicare in the 1960s using future president Ronald Reagan to make a recording that warned: "The doctor begins to lose freedom. It's like telling a lie and one leads to another. One day we will awake to find that we have socialism."

The AMA swung behind the House bill in the summer, though, declaring "we've decided on a course that is decent and civilized," and recently fended off dissidents' attempts to reverse that support.

"So, the AMA is at a crossroad," its president, Dr. J. James Rohack, told members. "In a crisis, true character is revealed. Times change, situations change, technology changes, the landscape may be altered, but basic values must not."

Those values?

"Universal access, pluralism, freedom of choice and freedom of physician practice."

Self-interest is, of course, part of the equation: Doctors want to keep their seat at the table as they fight to roll back substantial cuts scheduled for payments they receive under Medicare.

Other health care lobbies, also former foes of reform, have helped the Obama administration even while fighting aspects of the bills. Drug makers and hospitals, for example, agreed to absorb more than $\$ 200$ billion in costs over the next decade to ease the government's expense.

What gives?

"The simple answer is that they've been promised a deal," Marshall says. "There are going to be more customers coming in. By and large, they are healthy and younger folks whose medical bills aren't as big as others. So they've seen a way they can do well in the universe of expanded coverage."

A year of economic distress has also helped to empower the will to take on health care, opening an opportunity for broad changes. As Obama's harddriving chief of staff Rahm Emanuel put it: "You never want a serious crisis to go to waste."

So, close, yes. But failure is still a possibility.

Democrats are struggling to keep their ranks together, for they can't afford to lose a single vote. So far, they don't have that unity and it's a mystery how they'll get it.

One problem is that Democrats are having a rare dispute over abortion. Some say the Senate bill does not do enough to block federal tax dollars from being used for abortion coverage.

Under Senate rules, Democrats need the votes of all 60 in their caucus not just a simple majority of 51 - to stop Republicans from delaying legislation to death.

Should the initiative emerge from the Senate, both houses of Congress will need to reconcile their two versions, which could be markedly different after Senate amendments. They then must both pass the final "reconciled" legislation before Obama can sign it into law.

But at least a measure of civility appears to have now been introduced into the debate, after a summer of populist discontent during which, as Kathleen Hall Jamieson, director of the Annenberg Public Policy Center at the University of Pennsylvania, describes it, "crazed viral fantasies" took root online.

"The unengaged ad hominem of the town halls in August existed in another world," she says.

Away from the political extremes, what do average Americans want?

Polls have been so nuanced that both sides can claim the findings validate their views and neither side can prove it.

"People admit that it makes them nervous," says public opinion analyst Andrew Kohut, president of the Pew Research Center. "There's been a great deal of interest in health care reform. Though, when the question gets raised 
more specifically, the anxiety that it provokes begins to challenge the desire to see things change."

Even so, Kohut adds, Obama has assembled a broad coalition and seized a ripe moment. After Democrats sunk the attempt by former US president Bill Clinton and his wife Hillary to achieve an overhaul of health care in
1994, no serious Democratic contender for national office even dared propose universal coverage again for a decade. The Clintons had laboured largely in secret, producing a complex, micromanaged package that Congress snubbed.

But Obama, the "yes we can" man, let the legislators work up the legisla- tion. He seemed so pliable on details that people wondered at times what, exactly, he stood for. The process is more open this time. More measured, flexible, respectful of Congress. And still one audacious roll of the dice. Cal Woodward, Washington, DC

DOI:10.1503/cmaj.109-3132

\section{US health reform Q\&A}

Some questions and answers about the health care legislation making its way through the United States Congress:

\section{Q: Did Washington study Canada's experience?}

A: Admirers and critics of Canadian health care testified to Congress but their impact was minimal because the US is not following Canada's path.

\section{Q: Why not follow Canada's path?}

A: Democrats decided the only way to go was to build on the employer-based system, expand existing government offerings, make insurance more affordable and set new controls on private insurers.

Democrats have their passionate single-payer advocates. But that possibility ran aground on the broadly held view that government delivery of services is inefficient. As Will Marshall, founder of the Progressive Policy Institute, a centrist Democratic think-tank, notes: "The United States is exceptional in the sense it doesn't have a real socialist or social democratic tradition. There's a deep strain of antistatism that cuts across the usual political categories. For better or worse, that's the American ethic. That's why it's no accident that it's taken us so long to get to even a patchwork plan that covers almost everybody. There's a deepseated feeling that government ought not to help those who can help themselves."

\section{Q: So after all of this, some Americans still won't be} covered?

A: Right. About $95 \%$ of legal residents under 65 will have coverage if the legislation's goals are achieved. That's up from $83 \%$ now. Older people already have coverage from government, as do the poorest Americans. The millions of illegal immigrants will not be helped.

\section{Q: What will prompt more people to get insurance?}

A: The law, for starters. Insurance will become mandatory and people will be penalized in their taxes or fined if they don't get it from their employer, from a government plan or on their own. The only exception will be for people who obtain hardship waivers after demonstrating that they can't afford the financial blow despite subsidies.

In return, the government will set up new insurance markets and provide subsidies to make coverage affordable to more Americans.

\section{Q: Will insurance become cheaper?}

A: Subsidies should lower costs for many, but not all. The Kaiser Family Foundation estimates a family of four making US\$44 000 a year will pay US\$200 a month and a family making US\$66 000 will pay US\$550 a month, if provisions of the House bill become law. That's down from more than US\$1000 a month now.

Higher income people will get less help and might see little difference. The wealthiest Americans will pay higher taxes.

Young people could pay more. Insurers will face limits in their ability to set premiums based on age. That's bound to make insurance more expensive for young people and cheaper for older people.

Q: What are key differences between the House and Senate bills that will have to be reconciled before health reform becomes law?

A: The House bill proposes setting up a government insurance plan to compete in the private market, a key provision for many Democrats. The Senate has moved away from that "public option." To appease more conservative legislators, senators are proposing the creation of private, nonprofit insurance plans that would be overseen by the federal government. This boosts chances of health reform passing in the Senate but opens up potential fissures with the House. In addition, the House legislation puts more pressure on medium and large businesses to offer health insurance to workers.

\section{Q: What impact will the changes have on the US health care system?}

A: The US system will come under tremendous pressure to deliver higher quality care for more people and with much less waste if this overhaul takes effect. Electronic record keeping, comparative effectiveness research and many other promising and speculative efficiencies will be accelerated and put to the test as millions more people come into the insurance system and policy-makers struggle to pay for it all. 